\title{
SPEECH IN THE ROYAL PRESENCE: JAVANESE PALACE LANGUAGE
}

\author{
Joseph Errington
}

The Javanese speech levels have received considerable attention from linguists and lexicographers, but little has been written about a very specialized speech style used exclusively among the upper members of the priyayi elite, who once defined standard Javanese usage. Within the highest male priyayi circles of Yogyakarta and Surakarta (= Solo) a special "palace language" was in use, known in the latter city as basa kedhaton, in the former more generally as basa bagongan. Names, forms and uses of palace language have varied from locale to locale and from time to time, but one basic contextual feature crucially and consistently defined palace language: it was exchanged among courtiers when speaking in the presence of the king in formal audience, and/or at his behest. A common Javanese phrase referring to this place--ing ngarsa dalem, "in the royal presence"--connotes a conception of ruler as locus of power and definer of an area within which special modes of behavior are obligatory. ${ }^{I}$ In this respect, palace language is a special manifestation of a particular ideology of kingship and politics.

What follows is intended as a supplement to Poedjosoedarmo's wordlist of nonngoko vocabularies, together with a very broad and somewhat tentative characterization of palace usage. ${ }^{2}$ Palace language is set off from the "everyday" speech levels by the same types of features through which non-ngoko and ngoko speech are distinguished, and the palace language forms can be divided into subclasses functionally analogous to various subsets of the "everyday" speech level wordclasses. For this reason, the basic Javanese metalinguistic vocabulary presented in Poedjosoedarmo's description of the speech levels can and will be used here, in accordance with the definitions and descriptions he provides. ${ }^{3}$

Difficulties in dealing with palace language stem from its double marginality. First, crucial distinguishing marks setting it off from "everyday" speech are found for only a small number of lexical/morphemic contrasts. Second, palace language

1. The area within which palace language was obligatory (and so the royal presence) was defined very precisely in terms of the location and purpose of a given audience. Four such types of audience are distinguished in the Serat Wewaton Tata-krama, Pisungsungipun Radèn Ngabêhi Jayadarsana Kaliwon Gandhèk saking mara sepuh Radèn Ngabéhi Ranggawarsita (Surakarta: Mesiom Radyapustaka ms. \# 74, Javanese character catalog).

2. Soepomo Poedjosoedarmo, "Wordlist of Non-ngoko Vocabularies," in Indonesia, 7 (April 1969), pp. 165-90. Note that his spelling conventions are not used here; the orthography in this paper is adapted from the Javanese spelling system brought into conformance with Indonesian orthography. But front mid-high and mid vowels are transcribed /ê/ and /è/ respectively, and so distinguished from schwa which is transcribed as $/ \mathrm{e} /$.

3. Soepomo Poedjosoedarmo, "Javanese Speech Levels," in Indonesia, 6 (October 1968), pp. 54-81. 
had only an artificial type of use, and so was clearly susceptible to manipulation and modification in much more far-reaching ways than were other non-ngoko vocabularies. This was primarily a function of the smallness and cohesiveness of the group which spoke it, their unanimous deference to the king, as well as the restricted number of occasions for its use. Thus, even a superficial description must be essentially comparative and historical; only in this way can one account for differences between the written descriptions on which one must perforce depend. Such descriptions are crucial because palace language is itself largely history, having been effectively extinct in Surakarta as a regularly used subcode since the beginning of the twentieth century; in Yogyakarta, basa bagongan is reportedly still used, but younger servants of the royal house (abdidalem) do not control it nor feel obliged to use it. ${ }^{4}$ It is, then, at least moribund, if not obsolete.

Several texts attribute the origins of palace language to the mythical king Sindhula of Galuh (on the northwest coast of Java), who ordered his prime minister, Raja Kapa-Kapa, to devise a special language. ${ }^{5}$ The king had become conscious of his special status as kalipah, "God's representative on earth," and consequently of the collective inferiority of courtier and commoner alike in his presence. In royal audience, status distinctions between them were insignificant, and palace language was therefore developed as a code used collectively and reciprocally to equalize linguistic indexing of their status vis-à-vis each other. This is in any case the motive attributed to Anyakrakusuma (1612-45), who reinstituted the language in the forms which were to be inherited by the Susuhunan of Kartasura and (later) the Sultan of Yogyakarta.

This quasi-official account clearly reflects the basic ideologized function of palace language as a style of address obligatorily used in symmetric exchange in the royal presence. Because use of speech levels to mark status differences was always patterned asymmetrically, such enjoined symmetry marked a suspension of mundane social attributes of speaker and addressee, and so in a negative or indirect fashion marked deference for a very special third person: the king. ${ }^{6}$ As such, palace lan-

4. In modern Surakarta, basa kedhaton is now heard only in (very rare) official audiences, and then in use by a special official--the gandhè $k$--who may address the king in audience with this vocabulary. It is pronounced with a marked semi-chanted rhythm (ulon), as described by Benedict Anderson in his article "Diachronic FieldNotes on the Coronation Anniversary at the Kraton Surakarta Held on December 18, 1963," in Indonesia, 3 (April 1967), pp. 62-71. See also Astuti Hendrato, "Bahasa kedhaton: bahasa yang masih hidup tetapi tidak dikenal orang," published in Bulletin Yaperna, no. 7 (1975), but cited here as a stenciled typescript.

5. Several sources include a pair of chronograms for this occasion. For the lunar year is given a candrasangkala: Luhuring carana kombuling nata ("Nobility of adornment is the glory of the king"), or 1020. For the solar year is given the suryangkala: Muka gapura wiwara("Before the royal entrance gate[?]"), or 999. On Sindhula and the kingdom of Galuh, see H. J. de Graeff and Th. G. Th. Pigeaud, De Eerste Moslimse Vorstendommen op Java: Studiën over de Staatkundige Geschiedenis van de 15de en 16de Eeuw (The Hague: Nijhoff, 1974).

6. The same types of rules of equalization were instituted for all marks of status differences in conduct and, to an extent, in accoutrements. Particularly important in this regard were rules for the sembah (gesture of fealty). Texts like the Serat Wewaton . . . cited above are quite explicit as to the number of sembah to be given to the various high-ranking nobility, depending on where they were encountered. In general, the number of sembah decreased with proximity to the king's residence (dalem), and in audience, aside from the king, only the crown prince was entitled to a sembah from the courtiers and noble elite. 
guage was a special type of bystander-honorific address style, which complemented an often conspicuous nonuse of krama inggil for reference to any save that bystander. The specialness of the palace address forms (as opposed, for instance, to symmetric ngoko or krama) simultaneously set the entire situation off from any "ordinary" occasion of language use.

\section{The Basic Vocabulary of Address}

Morphemes of what will be henceforth called the "core" palace vocabulary are synonymous and so glossable with their "basic" ngoko equivalents, as shown in Table 1. This vocabulary marks a distinct way of speaking to people rather than of them; it defines a style of address, not reference. It is not surprising, then, that it shares a common functional basis with the leveled sets of "everyday" Javanese conjugates which contain not just ngoko and krama, but also madya elements. ${ }^{7}$ They are primarily grammatico-functional elements (syntagmatics), such as auxiliary verbs and affixes, but also demonstrative pronouns (inherently dependent on context of use), and elements used to perform actions directed necessarily to an addressee: answering questions, inviting, and so on. (Personal pronouns occupy a special place in the "everyday" speech levels and palace language alike, to be dealt with below.)

Note that in palace language, the three-way deictic distinction found in ngoko does not collapse into a single term as it does in krama; rather, the distinction between the deictic member associated with speaker (ngoko $=i k i$ "this") and addressee (ngoko $=i k u$ "that") is preserved. ${ }^{8}$ In krama, indirect allusion to the speaker/addressee relation is obligatorily avoided through use of only the third-person term (ngoko = kaé, krama = menika) "that far from speaker and hearer." In palace language, it is exactly a third person or bystander--the king--to whom one must avoid allusion, be it merely through use of a demonstrative pronoun linked to a third person. This complementarity of deictic collapse in "everyday" krama and palace language correlated directly with their basic pragmatic foci: speaker/addressee on one hand, courtier/king-bystander on the other.

Because palace vocabulary, like madya, contains very few unique referential lexemes, speech in the royal presence necessarily contained lexemes from another speech level. In madya, one has the option of "raising" or "lowering" politeness through choice of krama or ngoko elements, respectively; in palace language, usage was obligatorily symmetric krama. The Solonese address style was later elaborated through introduction of a number of lexical-referential as well as syntagmatic elements, but the crucial function of the vocabulary in Table 1 is attested by the fact that, when the vocabulary shrank again, grammatico-functional elements remained after lexically referential material had become obsolete.

7. Those elements of ngoko or krama which are obligatory elements of madya as well are treated here as madya. Affixes such as $k a-$ and di- (passive markers), -é (genitive and nominal marker) and -aké (causative and benefactive marker) are cited as palace language in most texts, and are used in all examples of palace language. For more on the structure of madya, see Poedjosoedarmo, "Javanese Speech Levels," and Joseph Errington, "Changing Speech Levels among a Traditional Javanese Elite" (Ph.D. dissertation, University of Chicago, 1981), pp. 357-405 and 458-561.

8. See E. M. Uhlenbeck, "The Javanese Pronominal System," in Studies in Javanese Morphology (The Hague: Nijhoff, 1978), pp. 210-77. 
TABLE 1

BASIC PALACE VOCABULARY

\begin{tabular}{|c|c|c|c|}
\hline Palace Language & ngoko & Indonesian & English \\
\hline besaos* & waé, baé & saja & only, just, even \\
\hline boya & ora & tidak & no, not \\
\hline nedha & $\begin{array}{l}\text { ayo, mangga, } \\
\text { enya }\end{array}$ & $\begin{array}{l}\text { silahkan, } \\
\text { ayo }\end{array}$ & please (inviting) \\
\hline enggèh & iya & ya & yes, affirmative \\
\hline manira & aku & aku & $\mathrm{I}$, me, mine \\
\hline pakenira & kowé & kamu & you, yours \\
\hline punapi & apa & apa & $\begin{array}{l}\text { yes/no question marker, } \\
\text { object marker, head noun } \\
\text { of indefinite relative } \\
\text { clause }\end{array}$ \\
\hline puniki/puniku & $\mathbf{i k i / i k u}$ & ini/itu & this/that \\
\hline séyos* & séjé, béda & $\begin{array}{l}\text { berbeda, } \\
\text { berlainan }\end{array}$ & $\begin{array}{l}\text { different from, not in } \\
\text { agreement with }\end{array}$ \\
\hline wawi & $\begin{array}{l}\text { ayo, mangga, } \\
\text { enya }\end{array}$ & $\begin{array}{l}\text { silahkan, } \\
\text { ayo }\end{array}$ & please (inviting) \\
\hline wènten* & ana & ada & there is/are \\
\hline $\mathbf{k a}-/ \mathrm{di}-$ & di- & di- & impersonal passive \\
\hline -é & $-\hat{e}$ & - nya & $\begin{array}{l}\text { genitive marker, } \\
\text { nominalizer }\end{array}$ \\
\hline -aké & -aké & -kan & $\begin{array}{l}\text { causative/benefactive } \\
\text { verb marker }\end{array}$ \\
\hline
\end{tabular}

* According to Walbeehm these forms had fallen out of use by 1895 . See A. H. J. G. Walbeehm, De Taalsoorten in het Javaans (Jakarta: Albrecht, 1897). 
Solonese texts name the entire address vocabulary of which the core is a subset as tembung ngagok wicara ("words to make speech awkward") or tembung mangéka praya ("words to unite the hearts"). Both phrases capture well some of the phonoaesthetic and social peculiarities of the vocabulary. On one hand there are obvious similarities and even identities between the forms in Table 1 and numerous madya and krama désa ("village krama") items, e.g., séyos, wènten, enggèh, besaos. In this respect, speakers of palace language conducted themselves like speakers who were (and to an extent still are) perceived by priyayi as lower-class and uneducated. Thus, Padmosoesastra says quite explicitly that these words can be grouped together with madya. ${ }^{9}$ If the etymology attributing the Yogyakartan term basa bagongan to the mannerisms of Bagong (third and youngest son of Semar) is correct, then it seems that a role like that of the punakawan (coarse servant of the refined noble) was mandatory before the king. ${ }^{10}$

To equalize speakers in a highly stratified society was simultaneously to unite them; this alternate sort of function attributable to palace language was captured by a high-ranking Yogyakartan priyayi who made up the following sentence entirely out of the basa bagongan words: Manira, pakenira, nedha, puniku-puniki boya wènten punapi-punapi, enggèh? "Please, between you and me there should be no problems at all, right?" 11 Such a retrospective attribution of democratic intent does in fact contain an element of truth, even if such putative equality was in reality predicated on the exaltation of the king. ${ }^{12}$

Table 1 exhausts the vocabulary of Yogyakartan basa bagongan, and it seems that the simplicity of the crucially distinctive vocabulary has been complemented by relative stability in basa bagongan's membership and rules for use. (The only reported change in membership occurred when Hamengkubuwana VII [1877-1921] eliminated the word séyos.) ${ }^{13}$ Another royal decision apparently changed rules of use such that a distinction was made between princes of the realm (pangeran) and other courtiers: krama affixes (together with basa bagongan vocabulary) were used to pangéran in place of the ngoko affixes (thus, dipun-, -ipun, and -aken in place of di- or $k a^{-},-\bar{e}$, and -aké). ${ }^{14}$ Surakarta saw the introduction of numerous new elements which were used in a variety of ways.

Whether or not the antagonism between the two royal polities was directly responsible for the florescence of basa kedhaton, it was clearly part of the assiduously

9. Oerapsari (Jakarta: Kolff, 1915), p. 6.

10. Further information on palace language might well come from the traditional basa pedhalangan ("puppeteers' language") but sources on this oral/literary style will perforce go unused here

11. Quoted in Hendrato, "Bahasa kedhaton," p. 7. Her text actually gives "puni$k a-p u n i k i, "$ this first element obviously a typo.

12. This is the force of descriptions in ibid. and Parhadi, "Bagongan, bahasa demokratis di lingkungan kraton [Yogyakarta]," Kedaulaton Rakyat, April 19, 1980. Doubtless of far greater importance was the fact that the Sultan of Yogyakarta himself exchanged krama with nonintimate subordinates on a day-to-day basis.

13. Reported in Hendrato, "Bahasa kedhaton," p. 7. I infer that the word she wishes to specify here is seyos from her statement (in Indonesian) that the Javanese word for lain was eliminated; séyos is the obvious candidate.

14. Ka- apparently functioned in palace language with the same linguistic meaning as di-, but was presumably more literary and elegant in style. 
cultivated "cult of glory" which surrounded Javanese kings. ${ }^{15}$ As such, it was one of the several symbolic resources to which the elite had recourse for legitimation, especially as politico-military prerogatives were progressively withdrawn by the Dutch. It is possible likewise that the Yogyakartan conservatism in this regard reflects an indirect affirmation of descent from Sultan Agung by maintenance of the old ways, whereas Solonese innovations in palace language (and much else) mark a conception of a "true" inheritance which, as such, may be modified at the "true" king's whim. In any case, the basa kedhaton of Surakarta was apparently changed by royal fiat not long after Pakubuwana II (1702-49) moved there from the razed palace of Kartasura in 1744.

\section{Elaborated Solonese Address Style}

Table 2 lists the nonpronominal address forms included in reliable texts on Solonese basa kedhaton, but not mentioned as part of basa bagongan. All supplement the core vocabulary, and function as tembung ngagok wicara; most are likewise grammatical in function. The largest single lexically referential group has a semantic range pertaining to error, mishap, or misfortune (i.e., gonah, ketambetan, kèndran, unya, wikana), which seems to have been a special focus for euphemistic elaboration.

It is not clear just when these words were instituted officially as basa kedhaton; as noted above, rules of use for the entire subcode were reportedly changed by Pakubuwana II soon after moving to Surakarta from Kartasura. He decreed that only high-ranking servants (at or above the rank of kliwon) would be permitted to use basa kedhaton. Other subordinates were obliged to speak krama reciprocally with each other in audience, and in all probability exchanged reciprocal krama with their superiors as well. ${ }^{16}$ Exceptions to this rule were by royal fiat and could be made in the case of servants in charge of certain royal possessions about which they might have occasion to speak in audience ( see below). So officials came to be effectively divided into two great classes in the royal presence, and the original ideology espoused as the motivation for use of the language was thereby subverted. Walbeehm's work indicates that this florescence of palace vocabulary (if not changes in rules of use) was followed by effective erosion, such that by 1895 vocabulary items in actual use were far fewer, most of them apparently of the original "core" vocabulary listed in Table 1 . It is of course possible that these prescribed lexemes were in fact only optional or perhaps even entirely unused on a regular basis. By 1895 the palace language was in use only among official messengers when delivering royal pronouncements.

\section{Personal Pronominal Usage}

Members of the category of personal pronouns used to be as crucial for mediating personal relationships inside the palace as today they are outside in "everyday" speech levels; they were a special locus for elaboration and exhibited relative volatility. The pronouns pakenira and manira had originally been used, it seems, between all speakers when in the royal presence, and in any letter not addressed to

15. See Soemarsaid Moertono, State and Statecraft in Old Java: A Study of the Later Mataram Period (Ithaca, N.Y.: Cornell Modern Indonesia Project, 1963).

16. I infer this from examples and from pronominal usage prescribed in these situations: kula and ijengandika are both used in krama in nonpalace language varieties of speech. Note that the now somewhat old-fashioned madya second person pronoun ndika is obviously related to ijengandika. 
TABLE 2

ELABORATED SURAKARTAN ADDRESS FORMS

\begin{tabular}{|c|c|c|c|}
\hline Palace Language & ngoko & Indonesian & English \\
\hline $\begin{array}{l}\text { bénah, béna, } \\
\text { bènèh, bènten* }\end{array}$ & $\begin{array}{l}\text { séjé, gèsèh, } \\
\text { béda }\end{array}$ & $\begin{array}{l}\text { berbeda, } \\
\text { berlainan }\end{array}$ & not alike, different \\
\hline curigat & dhuwung & kris & ceremonial dagger, kris \\
\hline darbé & duwé & punya & have, own \\
\hline dedegi $\dagger$ & jenengi & saksikan & witness, observe \\
\hline gonah $\dagger$ & weruh, lènjèh & $\begin{array}{l}\text { lihat/tahu, } \\
\text { longgar(?) }\end{array}$ & $\begin{array}{l}\text { know, sensual/incon- } \\
\text { stant(?) }\end{array}$ \\
\hline kadi pundi $\dagger$ & kepriyé & bagaimana & how about it? \\
\hline kèndran & ilang & hilang & get lost, disappear \\
\hline ketambetan & lali & lupa & forget \\
\hline kuda† & jaran & kuda & horse \\
\hline lebeg, lebak & énak & énak & pleasing, delicious \\
\hline $\begin{array}{l}\text { mekoten, } \\
\text { me(ng)kèten / } \\
\text { me(ng)koten }\end{array}$ & $\begin{array}{l}\text { mangkono, } \\
\text { mangkéné/ } \\
\text { mangkono }\end{array}$ & $\begin{array}{l}\text { begitu, } \\
\text { begini/ } \\
\text { begitu }\end{array}$ & $\begin{array}{l}\text { like that, } \\
\text { like this/ } \\
\text { like that }\end{array}$ \\
\hline meksih & isih & masih & still (auxiliary) \\
\hline meneri & kapinujon & kebetulan & as it happens \\
\hline meninga & ngerti, weruh & tahu, mengerti & know, understand \\
\hline olih & olèh & oleh & procure, agent marker \\
\hline $\operatorname{pojar}(\hat{e})$ & carita(né) & carita(nya) & story, what (he) said \\
\hline sardula $\dagger$ & sima & macan & tiger \\
\hline segu† & cekik & sedu & $\begin{array}{l}\text { have the hiccoughs, } \\
\text { hiccough }\end{array}$ \\
\hline seta, septa $\dagger$ & doyan & suka & like, of food \\
\hline tabeh & jam & jam & hour \\
\hline unya & lincat, mlèsèd & $\begin{array}{l}\text { curang, tidak } \\
\text { tepat }\end{array}$ & betray, be in error \\
\hline wanita† & wong wêdok & orang perempuan & girl, woman \\
\hline wikana & embuh & entah & I don't know \\
\hline
\end{tabular}

* Forms included here are taken from different sources, with the different but related ngoko glosses provided here as a group. As Walbeehm suggests in De Taalsoorten ( $p .234$ ), confusion arises when (as in some sources) the Javanese glosses are provided only in krama, and that krama gloss in turn functions as the equivalent of more than one ngoko word.

$\dagger$ These forms are listed in most but not all reliable sources, on which more below. 
the king which might nonetheless be read in his presence. In Yogyakarta, correspondence from superior to inferior would include use of these two pronouns, even if the king was writing to the crown prince, or issuing a general pronouncement (piyagem).

Table 3 lists the first and second person pronominal repertoires used in Solonese and Yogyakartan palace language. Most Solonese accounts specify that the king would refer to himself as ingsun in audience, and address others as sira; this was clearly the case in Yogyakarta as well. (Note that, although such use is characteristic of the audience situation, it does not count as palace language as defined above. This perhaps is why it is not explicitly mentioned in Yogyakartan accounts.)

TABLE 3

PERSONAL PRONOMINAL REPERTOIRES

\begin{tabular}{|c|c|c|c|}
\hline & for first person & l & for second person \\
\hline Yogyakarta: & manira & & pakenira \\
\hline \multicolumn{4}{|l|}{ Surakarta: } \\
\hline \multirow{3}{*}{$\begin{array}{l}\text { tembung mahasatata, } \\
\text { tembung manungkara }\end{array}$} & ingsun & & sira \\
\hline & mara & & para \\
\hline & manira & & pakenira \\
\hline \multirow{2}{*}{ tembung mangungkak basa } & f kula* & & (i) jengandika \\
\hline & robaya & & panten \\
\hline
\end{tabular}

* Ulun (or ngulun) is listed in some sources, but, according to Walbeehm, Taalsoorten, p. 228, was out of common use by 1895 .

In Surakarta, the king set off princes from all others through his use of the first person pronoun mara and second person pronoun para to them. These were in all likelihood developed as shorter (and so less polite) forms of manira and pakenira, respectively. These three sets of pronouns together--insung/sira, mara/para and manira/pakenira--are classified in some descriptions as tembung manungkara or tembung mahasatata.

The crown prince functioned as official head (pangerran pati) of the entire royal elite (putra sentana dalem), and like his father used mara and para to other princes, who presumably would have returned some deferential form. According to older sources, the comparable status of crown prince, the head of the government (patih), and the head of the army (sénapati), was marked linguistically by symmetric exchange among them of manira and pakenira; but, according to Walbeehm, the crown prince would also use mara and para to the prime minister, so (apparently) elevating him to a class with the princes. (Whether or not this was the result of the increasing amount of power which had fallen into the prime minister's hands by the latter part of the nineteenth century remains a topic for speculation.) In any case,

17. Walbeehm, Taalsoorten, p. 232. This was derived in turn from F. L. Winter's Serat Wewaton Tatakrama Kedhaton . . . discussed below. 
to all other priyayi in the royal government the crown prince traditionally used the first person panjenengan $(a) k u$ and second person sira, setting himself off from his father by the former pronoun. ${ }^{18}$

As with the use of ingsun/sira, it seems that what counted as "palace language" extended beyond those forms especially devised for royal audiences to include "everyday" forms as prescribed for employment in such audiences. Among members of the highest triumvirate, for instance, use of kin terms was prescribed as well, such that the prime minister and war minister were to be addressed as raka (this the krama inggil term for kakang ["elder male sibling"]) by the crown prince. They would respond with adhi ("younger sibling"). Crucial linguistic means for mediating social relations thus extended beyond special lexical forms. ${ }^{19}$

The prime minister was indirectly marked as the crown prince's inferior in their patterns of pronominal usage with governmental subordinates; in audience, the prime minister reportedly exchanged kula and ijengandika with his inferiors. Lastly, pronominal usage in basa kedhaton served traditionally to mark off a group of magico-religious officials including the pandhita (when such Hindu-Buddhistic priests were still appointed), pujangga (court poets), and panghulu (Islamic officials). Most descriptions indicate that these functionaries were to be addressed by the prime minister with the first person pronoun robaya and the second person pronoun panten, which they would likewise return. (Panten in all probability was derived as a kramanized form of para, itself a short form of pakenira.)

As incomplete as this outline may be, details on palace usage which may be gleaned from descriptions and examples are sufficient to indicate how, in Surakarta at least, personal pronouns were crucial and mutable linguistic elements for mediating interpersonal relations in the royal presence. In this respect, they functioned together with kin terms (as the few prescribed usages mentioned in the literature show) to delimit various status relations. The same was in all probability true for use of titles of descent, which were likewise highly susceptible to manipulation both in officially prescribed and actual day-to-day use.

These latter remarks are intended to point up the major yet unavoidable shortcoming of this brief presentation, stemming from insufficient information first about which prescribed forms in the texts consulted were actually used at any one time, and second about prescribed uses of "everyday" forms which were used in the royal audience, but also within the larger palace community. A full description of "palace language" in one of the several senses of the phrase discussed below would take account of all these possibilities. In fact, the same problem comes to the fore when one considers the final, essentially residual, vocabulary subset often mentioned in texts on basa kedhaton. This contains forms which mark deference through reference, and refer specifically to royal possessions.

18. In the reign of Pakubuwana $X$, royal servants were required to refer to (and address) the king with ijengandika when referring to a son of the king (so, "your son") born of a wife other than the queen (pramèswari). This is reported in a work entitled Piwulang Tata-krami Kraton Dalem Surakarta Amarengi Jumeneng Dalem Nata Sampéyan Dalem Ingkang Sinuhun Ingkang Minulya Saha Ingkang Wicaksana Pakubuwana $X$. This practice apparently was continued under Pakubuwana $X I$, according to priyayi who served under him.

19. So in royal audience all governmental officials were obliged to address each other as ki lurah, regardless of office or relative status. Even the highest of officials habitually treated each other in language as occupants of the lowest rank in the official hierarchy. 


\section{Deferential Reference in Basa Kedhaton}

The "core" and "elaborated" vocabularies of palace language constitute basic forms of address (like ngoko and krama), but the smallest subset of words usually listed along with them in palace language word lists correspond in function to "everyday" krama inggil. The terms listed in Table 4 were used only for reference to royal property. Insofar as (and if in fact) they were used only in audience in addressing persons other than the king, they would function as bystander honorifics, marking the presence of (deferred-to) king as a bystander. At the same time, the functional link of these words to krama inggil vocabulary is clear: both mark speaker's deference through linguistic reference. If in fact such deferential words and phrases were in use outside the audience situation, then they could with equal validity be called a special subset of the krama inggil vocabulary, which would be used (as would other krama inggil words) for reference to the king. It should be noted in this regard that phrases like kagungan dalem and sumitra dalem were apparently deferential prefatory phrases which were always combined with a lexeme referring specifically to the animal in question. Unlike other palace language forms, they were always used by any servants responsible for animals, regardless of their rank. The euphemistic quality involved here appears to parallel the indirectness of reference of much of the "everyday" krama inggil, even if this latter is cultivated through ambiguity and polysemy rather than elaborated but specific reference.

If one considers a form like titihan turongga, which contains a lexeme of "everyday" krama inggil (titihan), the distinction between prescribed use of "everyday" and "special" palace vocabulary can be seen in fact to be blurred. And even if all these phrases are generally classified (like words in Table 1) as tembung ngagok wicara, the functional bases of the two subsets of vocabulary differ. Lack of further information concerning a word like muncang, or words such as meninga, kuda, and segu listed in Table 2--were they in fact used only for the king?--makes it difficult to say where the line is to be drawn between "everyday" language and basa kedhaton. A comparison of Table 4 with Poedjosoedarmo's wordlist will indicate that some lexemes originally found in basa kedhaton were at the same time or in another period krama inggil as well, and so presumably available for use to mark deference for deferred-to referents other than the king. ${ }^{20}$

\section{What Counts as Palace Language?}

It is possible to distinguish three different meanings of the phrase basa kedhaton, at least as it is used among various Surakartans. In the strict sense, it refers to the ceremonial vocabulary of address dealt with above--special forms used in audience. Second, it may refer to special uses of "everyday" language (such as krama inggil) used only for the king: kin terms (like raka and adhi mentioned above) as well as special personal pronouns (e.g., panjenenganaku). Similarly, the use of ingsun by the king is unique to the audience situation, but is not therefore palace language in the strict sense; this is doubtless why it is not mentioned explicitly in descriptions of Yogyakartan palace language.

Finally, the term basa kedhaton is used both by non-priyayi and priyayi detached from the palace community as a cover term for linguistic usage which they associate with the "palace group" (kalangan kraton). One form is the second person pronoun panjenengan dalem, which is in fact used within and without the palace walls by many priyayi. This way of identifying palace language as a social dialect takes for its focus the locus of the legitimation of elite priyayi status, namely, the

20. Poedjosoedarmo, "Wordlist," pp. 165-90. 


\section{TABLE 4}

DEFERENTIAL TERMS FOR THE KING

kagungan dalem*
miyara kuda*
mundhing*
sumitra dalem*
tembung
titihan turongga*
muncang
kapatedhan $\dagger$
candhoka $\$$
aluhung§

kagungan dalem*

* These forms were reportedly used in audience by those servants of ranks lower than kliwon who were specifically responsible for and obliged to report on the animals in their care. These speakers were an exception, then, to the rules restricting use of basa kedhaton mentioned above. In his description "Iets over de Basa Kedaton," in Tijdschrift voor Indische Taal-, Land-, en Volkenkunde (1894), vol. 37 , pp. 105-11, Oudemans lists titihan turongga, but states explicitly that it is actually krama inggil. He alludes here to the problem of defining "palace language," to be discussed below.

$\dagger$ Note that the root for this rather artificial form is the same as that for the "everyday" krama word for "eat" and (at one time) "ask (for something), " tedha.

\$ Mentioned only in Walbeehm, Taalsoorten, p. 226 .

$\$$ Mentioned only in ibid., p. 227; there is a further qualification that it was used only in the formula dinonganana kang aluhung "may the noble ones be prayed for." Although the exact context for use goes unspecified, it is obviously highly restricted. 
king's residence. ${ }^{21}$ A socially stratified conception of basa kedhaton is not surprising, perhaps, but problems are encountered as soon as one considers a few particularly thorny words which straddle the category so defined. This is really the difficult problem of clarifying historical relations between palace language and the "everyday" speech levels.

As the history of the first and second pronominal paradigms indicates quite clearly, even in the last century there was a tendency for formerly "high" words to "fall" in deferential value as they spread "out" and "down" the social hierarchy. So some idea of how long-standing and broadly distributed this process has been would be crucial to an understanding of the relation of palace language (in the narrow and wide senses of the term) and the non-ngoko speech levels. Consider as a particularly à propos example words derived from the root unjuk: ngunjuk/diunjuk, ngunjukaké/diunjukaké, konjuk, and munjuk. ${ }^{22}$ The first two forms are part of virtually every speaker's deferential repertoire, with the meaning "drink/be drunk" (said of a deferred-to person). But for members of the highest elite, the other derived forms are superdeferential equivalents of derivates of the krama andhap verb root atur (give/say), i.e., ngaturaké/diaturaké, katur, and matur, respectively. The forms - unjukaké and konjuk are synonyms of -aturaké and katur, but are used only in relation to the very highest of deferred-to persons, so, in speaking of an act of giving to the king, prince, or perhaps another high noble. Such derivates of unjuk are classified by non-priyayi and priyayi not close to the palace as basa kedhaton; high-ranking priyayi still close to the palace, on the other hand, will classify them as a very polite krama inggil. But members of both groups will categorize njunjuk/diunjuk as "regular" krama inggil.

Even though none of the derivates of unjuk count as palace language in the strictest sense--used only in official audience--these forms are important because they indicate something of the dynamics of interaction of elite and nonelite speechgroups. These same dynamics have been a crucial factor in the evolution of palace language and the everyday speech levels insofar as the two are related--albeit in ways which remain unclear. The information needed to understand fully the evolution of one of these will, by the same token, help us to understand the other. However such information might eventually be uncovered--historically and/or comparatively--it would provide a means for understanding a priyayi speech style which has rapidly become a part of Java's linguistic past.

\section{Notes on Sources}

It seems likely that all of the texts cited here in describing Surakartan palace language have descended ultimately from a common origin, namely two royal decrees (pranatan) in the offices of the government of Surakarta (kadipatèn), which were doubtless destroyed when that building was razed during the revolution. On the basis of these two works, F. L. Winter wrote his Serat Wewaton Tatakrama Tembung Kedhaton ingkang kanggé para abdidalem ageng alit ing kraton Surakarta Adhiningrat sarta Serat Waduaji (Treatise on etiquette of palace language for all servants, great and small, in the palace of Surakarta Adhiningrat, together with the Waduaii treatise). ${ }^{23}$ This work, in turn, was the basis for Walbeehm's later description,

21. On variation in use of terms for the speech levels in Surakarta, see Errington, "Changing Speech Levels," pp. 423-39.

22. Transitive forms are given in the order active $\left(n g^{-}\right) /$passive (di-) using ngoko affixes; the same situation holds for their krama conjugates.

23. Surakarta: L. A. Cekol, 1892. 
from which some of the changes in palace usage have been inferred. Oudemans also cites Winter's work. The great similarities between Oudemans' study, Padmosoesastra's Oerapsari, and the Layang Karthi Basa, ${ }^{24}$ indicate that all three stem directly or indirectly from this same secondary source.

Winter's work closely resembles the manuscript Serat Wewaton Tata-Krama, Pisungsungipun cited above (footnote 1). Whether or not this latter was in fact copied from a manuscript by Ronggawarsita, as its title indicates, it clearly is based on the same materials. It should be mentioned that, at least in the versions I have been able to consult, no work attributed to Raja Kapa-kapa--the Serat Raja Kapa-kapa in either manuscript or printed form--makes explicit mention of particular types of palace language. ${ }^{25}$

Two sources dealing with palace language have not been included in this description: one is a book entitled the Serat Mahawipara, ${ }^{26}$ the other a manuscript from the Reksapustaka library of the Mangkunegaran palace, entitled Tembung Kraton Kangge Para Nata. ${ }^{27}$ Both contain several tens of words unlisted in any of the sources mentioned above; many of them are otherwise classifiable as "village krama" (krama désa), archaic or archaicized Javanese (kawi), or krama inggil. The Serat Mahawipara dates from after the turn of the century and is apparently a compilation of vocabulary both from the sorts of official kraton documents used here and from this Mangkunegaran text (or one related to it). In the Serat Mahawipara one finds many of the words found in the Mangkunegaran manuscript, listed in the same (nonalphabetic) order. It seems likely that the author of the Serat Mahawipara himself did not control basa kedhaton, and he certainly does not report the same style described in older works. Examples are given in which the affixes -aken and -ipun (both krama) are used with lexemes of basa kedhaton; no mention of the ngoko conjugates of these affixes is made. This differs, then, from all earlier sources dealing with both basa kedhaton and basa bagongan. In addition, such examples as are provided in the Serat Mahawipara are inconsistent on some points with the wordlist that same work includes. Putative examples of palace language (with krama affixes) make use of the word wonten, for instance, which is the krama equivalent of wènten, the true basa kedhaton (see Table 1). So in the Serat Mahawipara one finds the following example, ostensibly addressed by the wadana gamel (head of the royal stables) to his subordinates: Ijengandika punapi wonten ingkang sampun angraosaken tegaranipun titihan dalem kiyayi anu? "[Among] you is there any who has already tested the gallop of the royal horse Kiyayi So-and-so?" Yet six pages previously, wènten was included in a list of "words to make speech awkward," the tembung ngagok wicara. 28

Perhaps, on a few ceremonial occasions, basa kedhaton may still be heard in one form or another in the royal presence, and so might be said to survive. But clearly the types of elaboration which once were instituted gave way long ago to a progressive simplification, both in contexts of appropriate use and distinctive vocabulary. In this respect, the fate of palace language may parallel the fate of the "everyday" speech levels themselves.

24. Jakarta: Kementerian Pengadjaran, Pendidikan dan Keboedajaan, 1952.

25. The printed version consulted lists no author or publisher; the manuscript version (somewhat longer) is $\mathrm{ms}$. \#97, Javanese character collection of the Radyapustaka Museum, Surakarta.

26. Published by Radèn Dirjasatama: Surakarta, 1912 .

27. Reksapustaka library of the Mangkunegaran, ms. \# T16.

28. On pages 10 and 4 , respectively. 